Eur. J. Clin. Chem. Clin. Biochem.

Vol. 29, 1991, pp. 45-50

(C) 1991 Walter de Gruyter \& Co.

Berlin - New York

\title{
Blood Coagulation and Fibrinolysis During Normal Pregnancy
}

\author{
By J.W.J.van Wersch ${ }^{1}$ and J.M.H. Ubachs ${ }^{2}$ \\ 1 Haematological Laboratory \\ 2 Dept. of Gynaecology \\ De Wever Hospital, Heerlen, The Netherlands
}

(Received July 5/October 25, 1990)

Summary: Fifty-six pregnant women (gestational age 6-40 weeks) were evaluated for their coagulation activation (fibrin monomers and thrombin-antithrombin III complex) and for their fibrinolysis profile by determining tissue plasminogen activator, plasminogen activator inhibitor, plasminogen, $\alpha_{2}$-antiplasmin and D-dimer. Fibrin monomers and thrombin-antithrombin III complexes were found to be significantly increasing with gestational age. All the fibrinolytic parameters showed a steady growth with the progress of the pregnancy, with the exception of tissue plasminogen activator which showed a significant decrease with gestational age, but mainly within the reference range. These results suggest a stimulation of the coagulation system and an activation of fibrinolysis with ongoing pregnancy, although the increasing $\alpha_{2}$-antiplasmin and plasminogen levels and the decreasing tissue plasminogen activator concentrations do not conform to this trend.

\section{Introduction}

From the literature, it is known that coagulation factors are increased during pregnancy, and this is particularly manifest in the third trimester. This is most striking in the case of the plasma fibrinogen concentration $(1-4)$, but it is also observed for factor VII and factor VIII, into a moderate extent for factor IX, factor X and factor XII. Factor II and factor V remain unchanged, whereas factor XI and XIII even show a decrease $(5-7)$. The general impression is that of a state of hypercoagulability, leading to the generation of thrombin. Once thrombin is formed, a series of reactions would be initiated leading not only to activation of the clotting factors II, V, VIII and XIII as a kind of positive feedback, but also of the last part of the coagulation cascade (fig. 1). Interaction with fibrinogen as a substrate results in the formation of fibrin monomers and subsequently of insoluble fibrin.

Interaction with antithrombin III as the regulator protein for thrombin activity leads to the formation of thrombin-antithrombin III complex. The formation of fibrin secondarily promotes the fibrinolysis

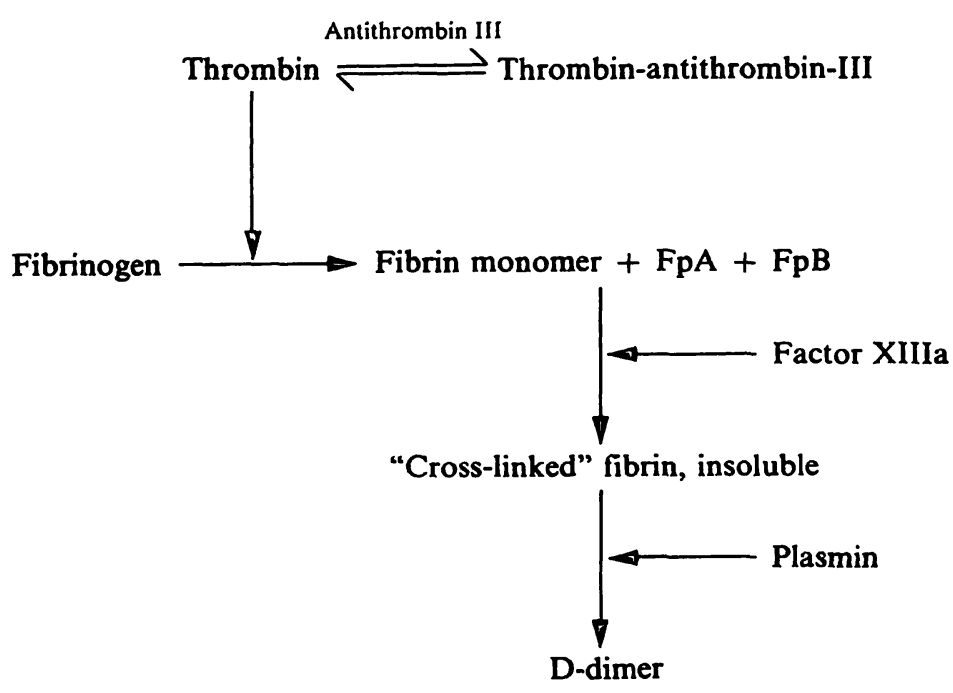

Fig. 1. Relevant part of the coagulation cascade $\mathrm{Fp}=$ Fibrinopeptide

system which produces the fibrinolytic agent, plasmin. Interaction of plasmin and fibrin produces the so called D-dimers, D-fragment dimers originating from cross-linked fibrin. There is much evidence that during pregnancy fibrinolytic activity (measured by means of 
the euglobulin clot lysis method and the fibrin plate method) is diminished, especially in the last trimester $(5,8-12)$.

More recent studies show that the plasminogen activator inhibitor also steadily increases throughout pregnancy $(13,14)$, whereas a special elevation is seen in pre-eclampsia $(15,16)$. Recently several new tests became available both for the investigation of coagulation activation and for the assessment of the level of fibrinolytic parameters. The aim of the present study was to collect information about the state of coagulation and fibrinolysis in the course of pregnancy. For this purpose the coagulation parameters, fibrin monomers and thrombin-antithrombin III, as well as the fibrinolysis parameters, D-dimer, tissue plasminogen activator, plasminogen activator inhibitor, plasminogen and $\alpha_{2}$-antiplasmin, were determined.

\section{Materials and Methods}

Individuals

Fifty-six pregnant women attending the department of gynaecology and obstetrics for monitoring of their pregnancy were included in the study. For the evaluation they were ranked according to their gestational age. The known duration of the gestation varied from 6-40 weeks and was based upon the last menstrual date and ultra sound determinations. Only patients whose last menstrual date and ultra sound determinations were congruent, were included in the study. As a control group we had at our disposal a group of subjectively healthy female hospital staff as well as female laboratory workers.

\section{Blood samples}

Blood samples were drawn between 8.30 and 9.00 a.m. after fasting overnight after a resting period of $20 \mathrm{~min}$. Except for tissue plasminogen activator activity, all coagulation and fibrinolysis parameters were determined in citrated plasma. This was prepared by centrifugation of a mixture of nine volumes freshly drawn blood with one volume trisodium citrate $(0.11$ $\mathrm{mol} / \mathrm{l})$ for $30 \mathrm{~min}(1600 \mathrm{~g})$ at $25^{\circ} \mathrm{C}$. The plasma was stored at $-70^{\circ} \mathrm{C}$ in plastic tubes and thawed with tap water for $5 \mathrm{~min}$ before serial analysis.

For the measurement of tissue plasminogen activator, $1 \mathrm{ml}$ citrated blood was added to $0.5 \mathrm{ml}$ acetate buffer ( $\mathrm{pH} \mathrm{3.9)}$, the mixture centrifuged immediately $(30 \mathrm{~min}, 1800 \mathrm{~g})$ and the plasma separated. The collected plasma was acidified with acetic acid (200 ml glacial acetic acid $+800 \mathrm{ml} \mathrm{H}_{2} \mathrm{O}$; final $\mathrm{pH}$ of the plasma sample $4.0-4.1$ ). This plasma was stored at $-70^{\circ} \mathrm{C}$ in plastic tubes and thawed with tap water for 5 min before analysis.

\section{Methods}

The fibrin monomer test was carried out with the Kabi Vitrum Diagnostica test kit Coa-set FM. For the thrombin-antithrombin III determination the Elisa kit of the Behring/Hoechst Corporation (Marburg, Germany) was employed. The Elisa Ddimer determination was performed with the test kit from the Boehringer Mannheim Corporation (Germany).

Plasminogen activator inhibitor as well as tissue plasminogen activator were quantitated by measuring the enzymatic activity of the plasmin generated in presence of fibrinogen fragments towards the synthetic substrate S-2251 (Kabi Vitrum Diagnostica).

Plasminogen and $\alpha_{2}$-antiplasmin reagents were from $\mathrm{Kabi} \mathrm{Vi}$ trum Diagnostica (Coatest plasminogen and Coatest $\alpha_{2}$-antiplasmin), both using the chromogenic substate S-2251.

\section{Statistical analysis}

Correlations were determined by linear regression analysis with the method of the least squares.

For the statistical comparison, Student's t-test was used.

\section{Results}

From 56 women with clinically normal pregnancies, the coagulation and fibrinolysis parameters, fibrin monomers, thrombin-antithrombin III, D-dimer, plasminogen, $\alpha_{2}$-antiplasmin, tissue plasminogen activator and plasminogen activator inhibitor were studied for their correlation with gestational age. The results are summarized in table 1 and figures $2-8$.

Tab. 1. Correlation between gestational age and different coagulation and fibrinolysis parameters.

\begin{tabular}{lcccc}
\hline $\begin{array}{l}\text { Linear correlation } \\
\text { between gestational } \\
\text { age and }\end{array}$ & $\mathrm{r}$ & \multicolumn{2}{c}{$\mathrm{y}=\mathrm{a}+\mathrm{bx}$} & $\begin{array}{l}\text { Signifi- } \\
\text { cance } \\
\mathrm{p}\end{array}$ \\
\hline Fibrin monomers & 0.51 & 7.8 & 0.16 & 0.002 \\
$\begin{array}{l}\text { Thrombin-antithrom- } \\
\text { bin III }\end{array}$ & 0.60 & 0.79 & 0.27 & $<0.0001$ \\
$\begin{array}{l}\text { D-dimer } \\
\text { Plasminogen }\end{array}$ & 0.58 & -5.26 & 34.1 & $<0.0001$ \\
$\begin{array}{l}\alpha_{2} \text {-Antiplasmin } \\
\begin{array}{l}\text { Tissue plasminogen } \\
\text { activator }\end{array}\end{array}-0.38$ & 121.1 & 0.87 & 0.003 \\
$\begin{array}{l}\text { Plasminogen activa- } \\
\text { tor inhibitor }\end{array}$ & 0.27 & 99.3 & 0.32 & 0.044 \\
\hline
\end{tabular}

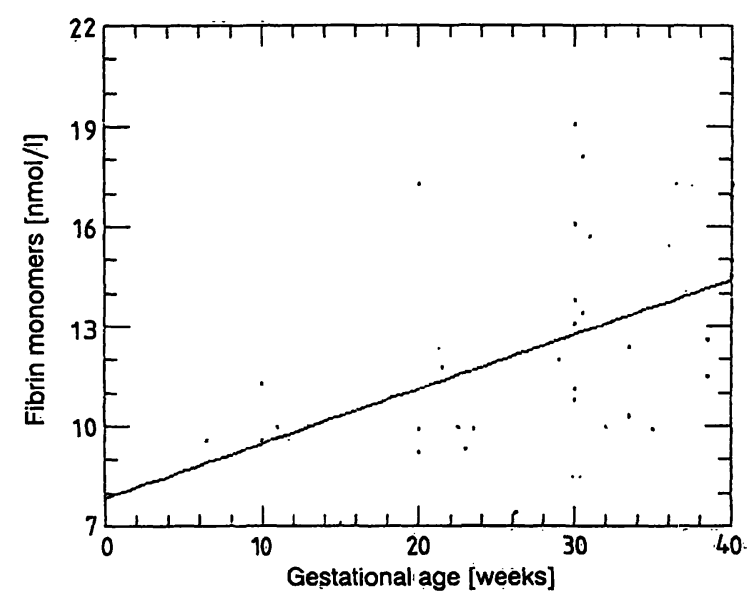

Fig. 2. Correlation between fibrin mọnomers and gestational age $(\mathrm{r}=0.51, \mathrm{p}=0.002)$. : 


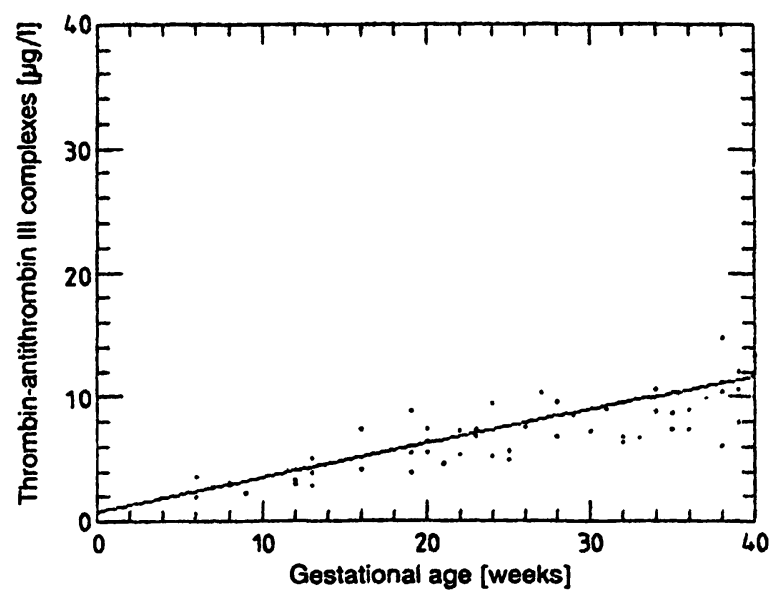

Fig. 3. Correlation between thrombin-antithrombin Ill complexes and gestational age $(r=0.60, p<0.0001)$.

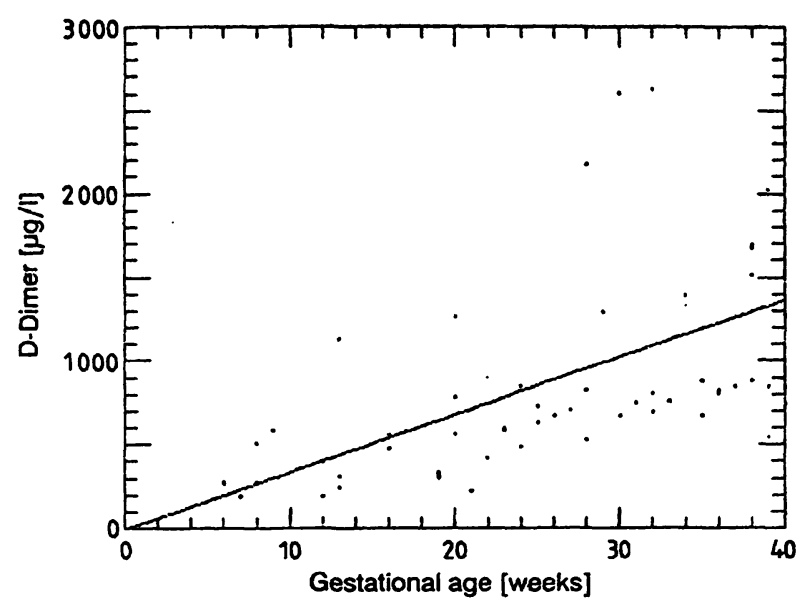

Fig. 4. Correlation between D-dimer and gestational age $(r=0.58, p<0.0001)$.

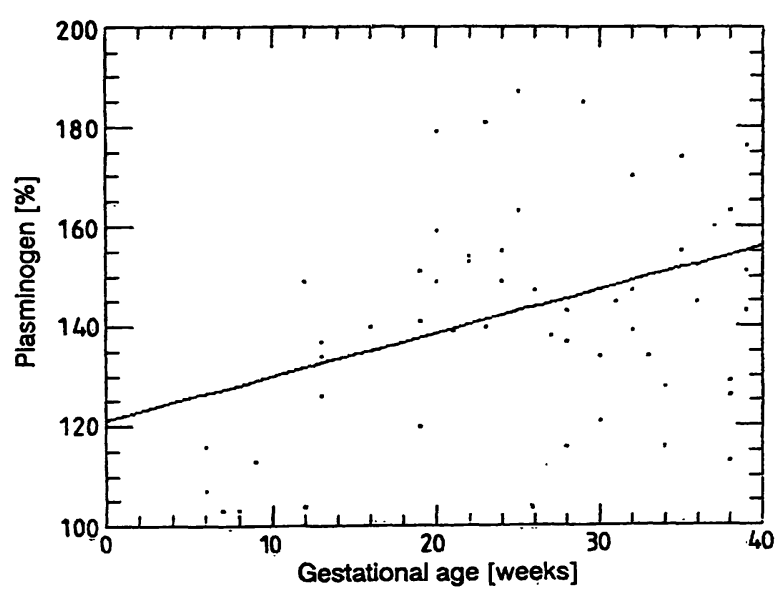

Fig. 5. Correlation between plasminogen and gestational age $(r=0.38, p=0.003)$.

All parameters were statistically significant on the $5 \%$ level of significancy. The coefficients of correlation indicated positive correlations for all but one (tissue plasminogen activator) parameter. For fibrin mono-



Fig. 6. Correlation between $\alpha_{2}$-antiplasmin and gestational age $(r=0.27, p=0.044)$.

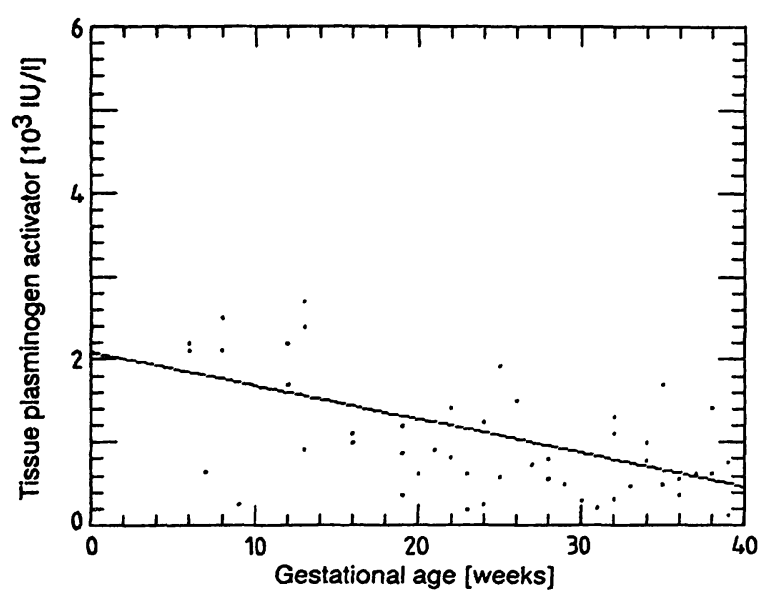

Fig. 7. Correlation between tissue plasminogen activator and gestational age $(r=-0.42, p=0.003)$.

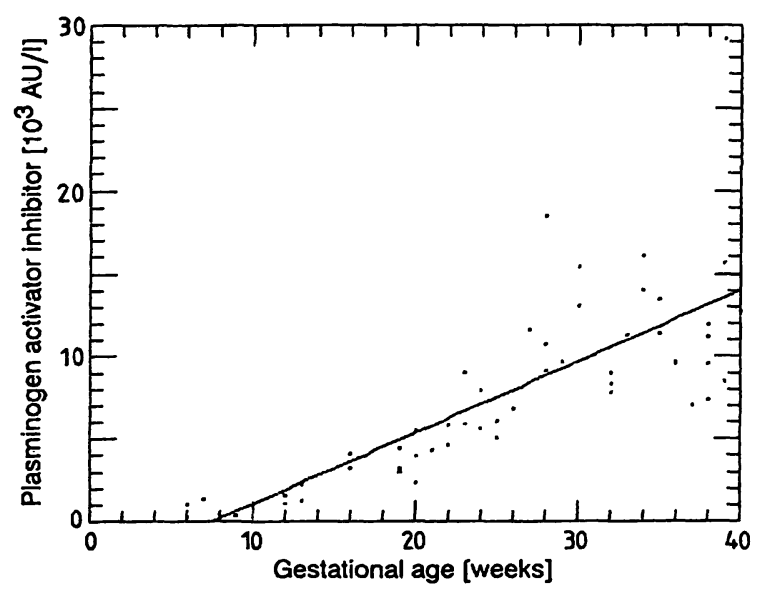

Fig. 8. Correlation between plasminogen activator inhibitor and gestational age $(\mathrm{r}=0.79, \mathrm{p}<0.0001)$. AU $=$ arbitrary units

mers a coefficient of correlation $(r)$ of $0.51(p=0.002)$ was found, for thrombin-antithrombin III $r=0.60$ $(p<0.0001)$, for D-dimer $r=0.58(p<0.0001)$, for plasminogen $r=0.38(p=0.003)$, for $\alpha_{2}$-antiplasmin 
Tab. 2. Position of the parameters with regard to the reference ranges (in brackets)

\begin{tabular}{|c|c|c|c|c|}
\hline Paramcter & $x$ & SD & $\begin{array}{l}\text { Values } \\
\text { beneath } \\
\text { the lower } \\
\text { reference } \\
\text { range limit } \\
(\%)\end{array}$ & $\begin{array}{l}\text { Values } \\
\text { above } \\
\text { the upper } \\
\text { reference } \\
\text { range limit } \\
(\%)\end{array}$ \\
\hline $\begin{array}{l}\text { Fibrin monomers } \\
(8.4-13.2 \mathrm{nmol} / \mathrm{l})\end{array}$ & 12.2 & 3.2 & 0 & 71.1 \\
\hline $\begin{array}{l}\text { Thrombin-antithrom- } \\
\text { bin III } \\
(1.0-4.1 \mu \mathrm{g} / \mathrm{l})\end{array}$ & 7.6 & 4.6 & 0 & 78.6 \\
\hline $\begin{array}{l}\text { D-dimer } \\
(0-450 \mu \mathrm{g} / \mathrm{l})\end{array}$ & 852 & 597 & 0 & 76.8 \\
\hline $\begin{array}{l}\text { Tissue plasminogen } \\
\text { activator } \\
\left(0.5-2.3 \times 10^{3} \mathrm{AU} / \mathrm{l}\right)\end{array}$ & 1.1 & 1.0 & 20.4 & 7.1 \\
\hline $\begin{array}{l}\text { Plasminogen activa- } \\
\text { tor inhibitor } \\
\left(0-4.6 \times 10^{3} \mathrm{AU} / \mathrm{l}\right)\end{array}$ & 7.6 & 5.5 & 0 & 64.3 \\
\hline $\begin{array}{l}\text { Plasminogen } \\
(85-130 \%)\end{array}$ & 143 & 23 & 0 & 71.4 \\
\hline $\begin{array}{l}\alpha_{2} \text {-Antiplasmin } \\
(80-120 \%)\end{array}$ & 107 & 12 & 0 & 14.3 \\
\hline
\end{tabular}

$r=0.27(p=0.044)$, and for plasminogen activator inhibitor $r=0.79(p<0.0001)$. The only negative correlation with gestational age was found for tissue plasminogen activator: $r=-0.42(p=0.003)$. Table 2 shows the position of the parameters overall in relation to the reference ranges. Only tissue plasminogen activator showed decreased as well as increased values $(20.4$ versus $7.1 \%)$. For all other parameters a considerable proportion of the data exceeded the upper limit of the respective reference ranges: for fibrin monomers $71.1 \%$, for thrombin-antithrombin III $78.6 \%$, for D-dimer $76.8 \%$, for plasminogen activator inhibitor $64.3 \%$, for plasminogen $71.4 \%$, and for $\alpha_{2}$ antiplasmin $14.3 \%$ of values exceeded the respective upper reference limit.

\section{Discussion}

The evaluation and interpretation of protein changes during pregnancy is complicated by the fact that they decrease with gestational age. This phenomenon is well known for total serum protein and serum albu$\min$ and is due to the redistribution of body water (i. e. rise of the plasma volume) with increasing gestational age (17). Also clotting and fibrinolysis parameters might undergo the same dilution effect. It therefore is the more astonishing that nevertheless $6 /$ 7 clotting and fibrinolysis parameters increase signif- icantly with gestational age. Until now the general impression was that the changes in coagulation parameters corresponded to a state of hypercoagulability. In this study we confirmed this statement by measuring fibrin monomers and thrombin-antithrombin III, both of which increase with gestational age, the levels being especially elevated in the last trimester of the pregnancy. These findings are in concordance with earlier reports $(3,18)$ in which circulating soluble fibrin monomer complexes were demonstrated from the beginning of the second month of the pregnancy, attaining maximal values five times the starting level at the end of gestation.

Fibrinolytic activity has been reported to be diminished in the last trimester of pregnancy $(5,8-10,12)$ when measured with the euglobulin clot lysis time and the fibrin plate lysis method. Moreover, several antiplasmins showed a significant trend to an increase during pregnancy, which might also imply a decrease in fibrinolytic activity $(2,6)$. In this study we found that the $\alpha_{2}$-antiplasmin activity and the plasminogen levels increase with the gestational age. Plasminogen activator inhibitor levels also increased significantly and steadily with gestational age. These results are in agreement with previous reports by Wiman et al. (13) and Kruithof et al. (14). It should be pointed out that the measured plasminogen activator inhibitor fraction consists of plasminogen activator inhibitor-1 and plasminogen activator inhibitor-2. Plasminogen activator inhibitor- 1 is considered to be mainly an endothelium component (19), whereas plasminogen activator inhibitor-2 originates from the placenta (20). Plasminogen, the natural occurring substrate of plasmin, is probably synthesized in the liver but also produced or stored by the eosinophil granulae. It can act in cooperation with a heparin binding basic protein as a local coagulation inhibitor (21). Possibly this is of importance, because there are several reports both of thrombotic manifestations in plasminogen deficiency and in plasminogen abnormalities (22) and of congenital plasminogen deficiency in relation to venous thrombosis (23). High plasminogen levels might be a protective measure against the over-activation of clot- . ting. On the other hand it could be a reflection of diminished plasmin generation. Indeed tissue plasminogen activator is the only one of the parameters which is found to be diminishing with gestational age. One would therefore expect a drop of the fibrinolytic activity during pregnancy. This conclusion can however not be drawn, when considering the overall endeffect of the fibrinolytic system during pregnancy: a significant increase of the D-dimer concentration with gestational age and $76.8 \%$ of the values above the upper limit of the reference range, $;$ This is in agreement 
with earlier studies of Arocha-Pinango (4), Gilabert (18) and Gordon (24), who reported indications of elevated fibrinolytic activity in vivo by demonstrating enhanced concentrations of fibrin(ogen) degradation products in the peripheral blood during the last trimester of pregnancy. Ballegeer et al. (25), however, demonstrated increasing levels of D-dimers with gestational age. These results indirectly suggest coagulation activation. Apparently, however, there is a kind of balance between coagulation activation and reactive fibrinolysis during perpetuation of pregnancy, although there is a tendency for tissue plasminogen activator to decrease and for plasminogen activator inhibitor and $\alpha_{2}$-antiplasmin to increase with increasing gestational age.

In summary, during the progress of pregnancy there is an elevation of coagulation parameters (fibrin monomers, thrombin-antithrombin III) and of the fibri- nolysis parameters, plasminogen, $\alpha_{2}$-antiplasmin, plasminogen activator inhibitor-1 and D-dimers, whereas tissue plasminogen activator showed a tendency to decrease. Especially the increasing levels of plasminogen activator inhibitor-1 and $\alpha_{2}$-antiplasmin as well as the decreasing tissue plasminogen activator levels are however not sufficient to impair the actual fibrinolytic activity, as can be concluded from the steadily increasing concentrations of the $\mathrm{D}$-dimers. It therefore remains questionable as to whether the combination of results allows the conclusion that the fibrinolytic activity decreases, leading to a thrombotic tendency during prengnancy, as stated earlier (13). The results reported here indicate a shift of coagulation and fibrinolysis during normal pregnancy. The findings can be valuable as a basis for the proper evaluation of the parameters studied in patients with risk pregnancies like pre-eclampsia, suspected foetal growth retardation, diabetes mellitus and thrombosis.

\section{References}

1. Oliver R. D., Patterson, B. B. \& Puls, J. L. (1976) Thrombin clottable determination of plasma fibrinogen in pregnancy. Obstet. Gynecol. 47, 299-303.

2. Condie, R. G. \& Ogston, D. (1976) Sequential studies on components of the haemostatic mechanism in pregnancy with particular reference to the development of pre-eclampsia. Br. J. Obstet. 83, 938-942.

3. Fletcher, A. P., Alkjaersig, N. K. \& Burstein, R. (1979) The influence of pregnancy upon blood coagulation and plasma fibrinolytic enzyme function. Am. J. Obstet. Gynecol. 134, 743-751.

4. Arocha-Pinango, C. L., Linares, J., Cova, A. \& Martinez, P. (1979) Is there a physiological intravascular coagulation in obstetrical cases? Acta Obstet. Gynecol. Scand. 58, $27=30$.

5. Nilsson, I. M. \& Kullander, S. (1967) Coagulation and fibrinolytic studies during pregnancy. Acta Obstet. Gynecol. Scand. $46,273-285$.

6. Royen, van E. A. (1974) Haemostasis in human pregnancy and delivery. Thesis Amsterdam.

7. Gjønnaess, H. \& Fagerhol, M. K. (1975) Studies on coagulation and fibrinolysis in pregnancy. Acta Obstet. Gynecol. Scand. $54,363-367$.

8. Brakman, P. (1966) The fibrinolytic system in human blood during pregnancy. Am. J. Obstet. Gynecol. 94, 14-20.

9. Bonnar, J., McNicol, G. P. \& Douglas, A. S. (1969) Fibrinolytic enzyme system and pregnancy. Br. Med. J. 3, $387-389$.

10. Astedt, B. (1972) On fibrinolysis. Part A: In pregnancy, labour, puerperium and during treatment with sex hormones. Acta Obstet. Gynecol. Scand. 51, 18-26.

11. Condie, R. G. (1976) Components of the haemostatic mechanism at birth in pre-eclampsia with particular reference to fetal growth retardation. Br. J. Obstet. Gynecol. 83, 943947.

12. Howie, P. W. (1979) Blood clotting and fibrinolysis in pregnancy. Postgrad. Med. J. 55, 362-366.

13. Wiman, B., Csemiczky, G., Marsk, L. \& Robbe, H. (1984) The fast inhibitor of tissue plasminogen activator in plasma during pregnancy. Thromb. Haemostas. 52, 124-126.

14. Kruithof, E. K., Tran-Thang, C., Gudinchet, A., Hauert, J., Nicoloso, G., Genton, C., Welti, H. \& Bachmann, F. (1987) Fibrinolysis in pregnancy. A study of plasminogen activator inhibitors. Blood 69, 460-466.

15. Aznar, J., Gilabert, J., Estelles, A. \& Espana, F. (1986) Fibrinolytic activity and Protein $\mathrm{C}$ in preeclampsia. Thromb. Haemostas. 55, 314-317.

16. Estelles, A., Gilabert, J., Espana, F., Aznar, J., GomezLechon, M. J. (1987) Fibrinolysis in preeclampsia. Fibrinolysis $1,209-214$.

17. Van Dieyen-Visser, M. P., Salemans T., van Wersch, J. W. J., Schellekens, L. A. \& Brombacher, P. J. (1986) Glycosylated serum proteins and glycosylated haemoglobin in normal pregnancy. Ann. Clin. Biochem. 23, 661-666.

18. Gilabert, J., Aznar, J., Parrilla, J. J., Reganon, E., Vila, V. \& Estelles, A. (1979) Alterations in the coagulation and fibrinolysis system in pregnancy labour and puerperium, with special reference to a possible transitory state of intravascular coagulation during labour. Thromb. Haemostas. 40, 387-396.

19. Booth, N. A., MacGregor, I. R., Hunter, N. R. \& Bennett, B. (1987) Plasminogen activator inhibitor from human endothelial cells. Purification and partial characterization. Eur. J. Biochem. 165, 595-600.

20. Estelles, A., Gilabert, J., Aznar, J., Loskutoff, D. J. \& Schleef, R. R. (1989) Changes in the plasma levels of type 1 and type 2 plasminogen activator inhibitors in normal pregnancy and in patients with severe preeclampsia. Blood 74, 1332-1338.

21. Riddle, J. M. \& Barnhart, M. J. (1965) The eosinophil as a source for profibrinolysin in acute inflammation. Blood 25, 776-794.

22. Girolami, A., Lazzaro, A. \& Sinioni, P. (1988) Thrombotic manifestations in plasminogen deficiency and in plasminogen abnormalitics. Thromb. Haemostas. 60, 528 (Letter).

23. Hach-Wunderle, V., Scharrer, J. \& Lottenberg, R. (1988) Congenital deficiency of plaminogen and its relationship to venous thrombosis. Thromb. Haemostas. 59, 277-280. 
24. Gordon, Y. B., Ratky, S. M., Sola, C. M., Lewis, J., Baker, L. R. J. \& Chard, T. (1975) Circulating levels of fibrin/ fibrinogen degradation fragment $E$ in normal pregnancy, and in association with intra-uterine growth retardation and perinatal asphyxia. Br. J. Obstet. Gynaecol. 82, 958963.
25. Ballegeer, V., Mombaêrts, P., Declerck, P. J., Spitz; B., van Assche, F. A. \& Collen, D. (1987) Fibrinolytic response to venous occlusion and fibrin fragment $D$-dimer levels in normal and complicated pregnañcy. Thromb. Haemostas. $58,1030-1032$.

Dr. J. W. J. van Wersch

De Wever Ziekenhuis Haematologisch Laboratorium Postbus 4446

NL=6401 CX Heerlen 